\title{
The utilisation of satellite imagery and community perceptions to assess the impacts of sea encroachment in the West Coast of Cameroon at Limbe
}

\author{
Mabel N echia Wantim ${ }^{1,2,3}$, Wase Albright Mokosa², Louis Jitiz ${ }^{3}$, Samuel N donwi Ayonghe ${ }^{1,2,3,4}$ \\ 1. Centre for Hazard Monitoring and Disaster Management (CED IM), Faculty of Science, University of \\ Buea, P.O. Box 63, Buea, Cameroon \\ 2. Disaster Risk Management Programme, Department of Environmental Science, Faculty of Science, \\ University of Buea, P.O. Box 63, Buea, Cameroon \\ 3. Natural Resource and Environmental Management Programme, D epartment of Environmental Science, \\ Faculty of Science, University of Buea, P.O. Box 63, Buea, Cameroon \\ 4. Interdisciplinary Climate Change Laboratory, Faculty of Science, University of Buea, P.O. Box 63, \\ Buea, Cameroon \\ * Corresponding Author
}

\begin{abstract}
ABST RACT
Coastal erosion associated to sea encroachment is a major problem at the West Coast of Limbe, specifically in the Debundscha Fishing Port (DFP). This study sought to assess the physical vulnerability of the West Coast of Limbe to coastal erosion associated to sea encroachment. This was achieved by assessing: i) the physical vulnerability of the West Coast to coastal erosion; ii) land cover changes and iii) community perception at DFP to sea encroachment and coastal erosion in the past 30 years. Three variables: rock type, adjacent land use and coastal protection were used to assess the vulnerability of the West Coast to coastal erosion. Landcover / coastal changes were assessed from satellite images from 1986 to 2018. Semi-structural interviews were used to acquire knowledge on the population's perception and impact of the studied hazards. A cost benefit approach was used to weigh the potentials of these localities to adapt to coastal erosion. The DFP and Idenau Beach were identified as major hotspots of coastal erosion with an annual rate of $>100 \mathrm{~m}^{2}$. Landcover changes showed a net increase in water levels inland and into settlements. The population is knowledgeable and is aware of the risk of sea encroachment and coastal erosion. The physical, socio-economic and health effects were: destruction of mangroves; relocation; malaria, typhoid and abdominal illnesses respectively. Coping strategies included the use of sandbags, building on higher grounds and on embankments. Cost benefit analysis ranked vegetative cover as the best option environmentally and financially viable to reduce coastal erosion from sea encroachment at the West Coast.
\end{abstract}

Key words: Sea encroachment, coastal erosion, physical vulnerability, perception, Debundscha Fishing Port

Received: 18/ 12/ 2020

Accepted: 18/ 01/ 2021

D OI: https/ / dx.doi.org/ 10.4314/ jcas.v16i3

(c) The Authors. This work is published under the Creative Commons Attribution 4.0 International Licence. 


\section{RÉSUMÉ}

L'érosion côtière associée à l'empiètement de la mer est un problème majeur sur la côte ouest du Limbe, plus précisément dans le port de pêche de Debundscha (PPD). Cette étude a cherché à évaluer la vulnérabilité physique de la côte ouest de Limbe à l'érosion côtière associée à l'empiètement de la mer. Elle a été réalisée en évaluant : i) la vulnérabilité physique de la côte ouest à l'érosion côtière ; ii) les changements de la couverture terrestre et iii) la perception de la communauté au PPD face àl'empiètement de la mer et à l'érosion côtière au cours des 30 dernières années. Trois variables: le type de roche, l'utilisation des terres adjacentes et la protection du littoral ont été utilisées pour évaluer la vulnérabilité de la côte ouest à l'érosion côtière. La couverture terrestre / les changements côtiers ont été évalués à partir d'images satellites de 1986 à 2018. Des entretiens semi-structuraux ont été utilisés pour acquérir des connaissances sur la perception et l'impact des risques étudiés par la population. Une approche coûts-avantages a été utilisée pour évaluer le potentiel d'adaptation de ces localités à l'érosion côtière. Le PPD et la plage d'Idenau ont été identifiés comme des points chauds majeurs de l'érosion côtière avec un taux annuel de $>100 \mathrm{~m}^{2}$. Les modifications de la couverture terrestre ont montré une augmentation nette des niveaux d'eau à l'intérieur des terres et dans les zones habitées. La population est bien informée et est consciente du risque d'empiètement de la mer et d'érosion côtière. Les effets physiques, socio-économiques et sanitaires sont les suivants : destruction des mangroves; délocalisation ; paludisme, typhoïde et maladies abdominales respectivement. Les stratégies d'adaptation comprenaient l'utilisation de sacs de sable, la construction sur des terrains plus élevés et sur des remblais. L'analyse coûts-avantages a classé le couvert végétal comme la meilleure option écologiquement et financièrement viable pour réduire l'érosion côtière due à l'empiètement de la mer sur la côte ouest.

Mots clés: Empiétement sur la mer, érosion côtière, vulnérabilité physique, perception, port de pêche de Debundscha 


\subsection{Introduction}

Approximately $40 \%$ of the world's population is within $100 \mathrm{~km}$ of the coast (Wong \& al., 2014; Neumann \& al., 2015) which host the main economic hubs of most countries (NOAA, 2017; Ayyam \& al., 2019). Unfortunately, globally, coastal zones are facing a good number of intensifying changes like sea encroachment, coastal erosion and floods stemming from natural and anthropogenic factors. Managing coastal flood risk is a crucial aspect since it affects developments, and is becoming increasingly important for coastal communities (Wadey \& al., 2015; Vousdoukas \& al., 2016, 2018).

Bird (2008) and Zhang e al. (2000) identified crucial factors for coastline change (e.g. geomorphology, wave action) and continuous beach erosion (e.g. sea level rise (SLR), human interference). Humans enhance sea-level rise through climate change, destruction and altering of coastal natural defences, over exploitation of coastal resources and continuous proliferation of settlement concentration (D omingos, 2016; Woodward, 2019). The geologic variables geomorphology and relief, account for a shoreline's relative resistance to erosion (Clark and Brabb, 1997). Rocky cliffs are less susceptible to erosion and inundation; while sandy beaches, deltas, and estuaries are vulnerable to erosion. The human variables, land use and artificial coastal protection, contribute to coastline erosion (Pendleton \& al., 2005).

0 ver $70 \%$ of the world's beaches are experiencing coastal erosion (Addo \& al., 2008; 2011; Luijendijk et al., 2018) linked to coastal flooding (Church \& al., 2013; Arnset \& al., 2017; Wahl \& al., 2017; Vitousek \& al., 2017; IPCC, 2019). Analyses of shoreline changes from 1984 to 2016, showed that a quarter of sandy beaches worldwide were eroding at a rate of $>0.5 \mathrm{~m}$ per year, shedding over $28,000 \mathrm{~km}^{2}$ of land to the sea (Abiy \& al., 2020). These rapid coastline changes, if not tackled adequately and timely, could lead to serious socio-economic consequences (Sun \& al., 2004; Skaggs \& al., 2006; Hussein \& al., 2020; Hoffken \& al., 2020).

Coastal erosion has damaged beaches in some West African countries such as Gambia, Senegal and Togo (Fagotto, 2016). Cameroon has between 360 and $402 \mathrm{~km}$ of coastline susceptible to sea encroachment, coastal erosion and pollution (Asangwe, 2007; Bienfang \& al., 2008; Joanna, 2012; Ouabo \& al., 2018). Kribi's coastline for example has eroded from about 50 to $100 \mathrm{~m}$ inland since 1990.

Unlike the importance given to, geological hazards like volcanic eruptions, landslides and earthquakes, less attention is given to coastal hazards in Cameroon. This is connected to the fact that coastlands are often considered as wasteland (A sangwe, 2007). Unfortunately, hazards in these zones like sea encroachment and coastal erosion could potentially result to a bigger humanitarian crisis (Famara, 2015).

The main objective of the study was to assess the vulnerability of all the West Coast localities to coastal erosion associated to sea encroachment from Batoke to Idenua. Specifically, the study was used to assess and evaluate: i) physical vulnerability of the West Coast to coastal erosion; ii) land-cover / land-use changes that have taken place in the past 30 years; and iii) the D ebundscha Fishing Port (DFP) community perception on coastal erosion and sea encroachment in the past 30 years. Findings from this research, will provide useful information needed to improve the understanding of the potential impacts of coastal erosion and sea encroachment in DFP and other West Coast localities. 


\subsection{Materials and Methods}

\subsection{Description of Study Area}

The West Coast of Limbe is found in the coastal lowland of Cameroon which lies within the Gulf of $\mathrm{G}$ uinea between latitudes $8^{\circ} 5^{\prime} \mathrm{N}$ and $9^{\circ} 15^{\prime} \mathrm{E}$ and longitudes $4^{\circ} 0^{\prime}$ and $4^{\circ} 15^{\prime} \mathrm{N}$ (Fig. 1). The Cameroon coastal lowland is characterized by sandy, low-lying swampy areas constantly intruded by saline water incursions from the Atlantic 0 cean (Kometa, 2012). The $35 \mathrm{~km}$ stretch of coastline moving from BatokeBakingili-D ebundscha-Njonji-Isobi-Idenau, falls under Fako Division of the South West Region of Cameroon (Fig. 1).

D ebundscha Fishing Port (DFP) is one of those areas along the West Coast which has been hardest hit by sea encroachment and coastal floods. According to the Idenua Council D evelopment Plan (CDP, 2011), D ebundscha has a population of $\sim 545$ people. This village is threatened by rise in sea level, eroding meters of the beach yearly. Sea-water invasion of settlement area and road infrastructure has led to the construction of an embankment at the highway leading to D FP. Many homes and businesses have been destroyed and the fishermen are finding it difficult to carry out their daily activities, thereby forcing the population to move on higher grounds. From field observation, if precaution is not taken, this village may one day disappear.

\subsection{Materials}

The satellite images used in this study were limited to those from the optical multispectral sensor. A total of five images were collected from the Landsat Thematic Mapper (1986), Landsat Enhanced Thematic Mapper + (ETM+ 2000) and the Landsat $8(2014,2017,2018)$ sensors. These images were acquired from the United States Geological Survey (USG S) website. Table 1 presents the different satellite dataset used in this work. Questionnaires were developed and used to collect data on the population's perception for coastal erosion and sea encroachment.
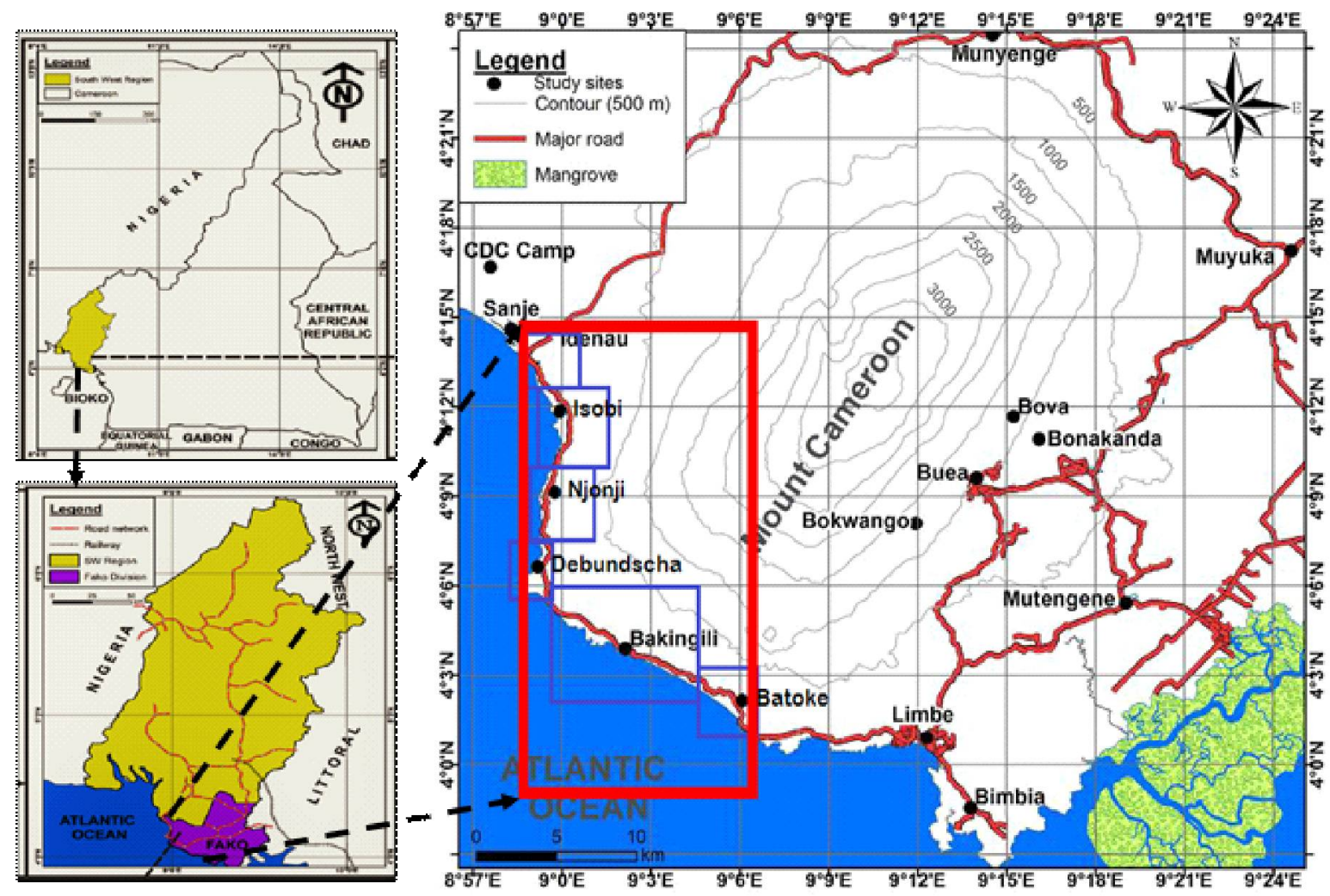

Fig. 1. Location of study area showing the West Coast localities 
Table 1: D etails on the satellite images (data) used in the study

\begin{tabular}{lllll}
\hline Sensor & $\begin{array}{l}\text { Date of } \\
\text { scene }\end{array}$ & $\begin{array}{l}\text { Pixel } \\
\text { Resolution }\end{array}$ & $\begin{array}{l}\text { Number } \\
\text { of bands }\end{array}$ & Applications (tied to study) \\
\hline Landsat TM & $12-12-1986$ & $30 \mathrm{~m}$ & 7 & Mapping land-cover change at \\
Landsat ETM+ & $10-12-2000$ & $30 \mathrm{~m}$ & 9 & the West Coast \\
Landsat 8 & $05-01-2014$ & $30 \mathrm{~m}$ & 12 & \\
& $18-01-2018$ & $30 \mathrm{~m}$ & 12 & \\
& & & & \\
\hline
\end{tabular}

\subsection{Methods}

\subsubsection{Vulnerability analyses to coastal erosion}

To determine the level of physical vulnerability of the West Coast to coastal erosion three variables were considered: i) geomorphology (rock type), ii) adjacent land use and iii) adaptation measures. G eomorphology was considered as the main variable influencing twice as the other two variables (Neuman, 2003). This reasearch adapted the Coastal Vulnerability Index (CVI) of HammarKlose and Thieler (2001) methodology. D ata and information on these variables were collected during field visits $(\sim 5)$ in the $35 \mathrm{~km}$ stretch that comprise the West Coast. Absolute ranking of the different parts of the West Coast was done using CVI values. The $35 \mathrm{~km}$ coastline was allocated 113 cells, with each cell covering 300.9 $\mathrm{m}$. In each cell, values of the three variables were summed and divided by the number of variables after which the calculated values were ranked using five categories of vulnerability: very high to very low (Table 2; Alexandrakis \& al., 2008).

\subsubsection{Land use / Landcover analyses}

The acquired satellite images (1986, 2000, 2014, 2017 and 2018) were processed using the ENVI 5.1 software. These images were stacked in pairs: 1986 and 2014, 2014 and 2017 and 2000 and 2018. This was relevant to resize them spatially (size) and spectrally (resolution). The subset used corresponded to the area occupied by the Idenau Municipality which hosts all the West Coast localities (Fig. 1). After the spatial and spectral processing, these images were then separated to begin the classification process.

The classification method used was supervised classification using the maximum likelihood option. This classification entails defining training sites (landcover classes) using the Region of Interest (ROI) tool in ENVI software. The training sites defined included: lava, montane forest, submontane forest, lowland forest, farmland, plantations, settlement, water bodies and cloud

Table 2: Coastal Vulnerability Index (CVI) assessment for the West Coast (adapted from HammarKlose and Thieler, 2001)

\begin{tabular}{|c|c|c|c|c|c|}
\hline Variables & $\begin{array}{c}\text { Very High } \\
\text { Vulnerability to } \\
\text { CE } \\
1\end{array}$ & $\begin{array}{c}\text { High } \\
\text { Vulnerabilty } \\
\text { To CE } \\
2\end{array}$ & $\begin{array}{c}\text { Moderate } \\
\text { Vulnerability to } \\
\text { CE } \\
3\end{array}$ & $\begin{array}{c}\text { Low } \\
\text { Vulnerability } \\
\text { to } \mathrm{CE} \\
4\end{array}$ & $\begin{array}{c}\text { Very Low } \\
\text { Vulnerability to CE } \\
5\end{array}$ \\
\hline Geomorphology & $\begin{array}{l}\text { Sand beaches, } \\
\text { Deltas }\end{array}$ & $\begin{array}{l}\text { Cobble beaches, } \\
\text { Estuaries, Lagoons }\end{array}$ & Ash cliffs & Ash+Pebble cliffs & Rocky cliffed coast \\
\hline Protection & Open & - & $\begin{array}{l}\text { Man-made } \\
\text { barriers }\end{array}$ & - & Natural barrier \\
\hline $\begin{array}{c}\text { Adjacent Land } \\
\text { use }\end{array}$ & Built up, road & Agriculture & Marshy Water & Shrubs & Forest \\
\hline
\end{tabular}


(Table 3). These classes were defined based on field knowledge of the area and using the Normalized Differential Vegetation Index (NDVI) tool in the ENVI software.

To determine the changes that had occurred over time based on the pairs, the overlay method based on generated vector themes of different years was used. Change detection was done between supervised classified images of 1986 and 2014; 2014 and 2017; and 2000 and 2018, using the first year as a common baseline data year for the period. The attribute tables of the output themes were summarized in definition tables to facilitate the compilation of areas of change for each information category.

\subsubsection{Community Perception analyses}

D ata was collected using questionnaires employing stratified random sampling method. Sampled members were selected base on: i) knowledge and experience of coastal hazards and ii) duration of stay ( $\sim 10$ years or more) at the West Coast. These interview sessions lasted for approximately 10 to 15 minutes using 'Pidgin English' for a better output.

Field visits were made from Batoke to Idenua (Fig. 1) between the period from June to August, 2018, to assess the perception of the population on coastal changes and adaptation. A total of 100 questionnaires were administered during this phase corresponding to 30 each for Batoke and DFP and 40 for Idenau Beach. The second phase of fieldwork took place from June to August 2020 at D FP where 74 respondents participated. Here the population's perception on sea encroachment and coastal floods was assessed, together with the socio-economic and health impacts they caused. For health impacts, the targeted diseases in the questionnaire included malaria, typhoid fever and other abdominal diseases. The prevalence of these diseases were based on the respondents' perception. This gave a grand total of 174 respondents mostly made up of fishermen and farmers with few businessmen, plantation workers and civil servants. The collected questionnaires were analyzed using the SPSS (Statistical Package for the Social Sciences) package.

Table 3: Land-cover classes classification and description

\begin{tabular}{ll}
\hline Land-cover classes & Description \\
\hline Lava & This refers to lava in the last century (1986, 1999 and 2000) \\
Lowland forest & Sparse forest below the mountain that can be used by farmers \\
Settlement & This constitutes built-up areas (roads, houses) and bare soil \\
Plantations & $\begin{array}{l}\text { Large hectares of land cultivated by corporations/ individuals for economic } \\
\text { purpose }\end{array}$ \\
Farmland & $\begin{array}{l}\text { Small hectares of land cultivated by individuals for subsistence agriculture } \\
\text { Water bodies }\end{array}$ \\
Cloud & Areas covered by cloud that made it impossible to define them \\
Montane Forest & Forests found at the top of the mountain \\
Sub-Montane Forest & Forest at the middle section of the mountain
\end{tabular}




\subsubsection{Cost Benefit analysis for adaptation to Coastal Erosion}

Cost-benefit analysis is an approach to estimate the strengths and weaknesses of adaptation strategies relevant to identify the best options. This analysis was used for coastal adaptation options such as shoreline protection; vegetative cover, beach nourishment (i.e. the supply of sand to the shore to secure the beach against erosion), and relocation as used on the Island of $\mathrm{O}$ ahu in Hawaii (Marchant, 2017). The aim was to identify the potential benefit of each option, its impact, and cost. Each variable was evaluated using the following parameters: social support; technical aspects; economic aspects; and environmental impact. The ranking of each option was from 1 (very low) to 4 (high) for the action's benefits and costs. The benefit to cost ratio determined which option should be given higher priority for consideration. Ratios that were greater than one were given higher priority, an equal ratio suggested benefits were equal to costs and are at a lower priority, and ratios that are less than one were given the lowest priority.

\subsection{Results}

\subsection{Ranking the level of vulnerability to Coastal Erosion in the West Coast}

In terms of rock types, the predominant landforms at the West Coast included: black sandy and cobble beaches; and ash and rocky cliffs. Areas of very high vulnerability corresponded to the black sandy beaches and included: Batoke, Tsaben and Bakingili beaches; D FP and Idenau beach (Figs. 2 and 3a). This made up $15.5 \mathrm{~km}$ (44.3\%) of the $35 \mathrm{~km}$ stretch. The rocky cliffs were the most stable areas characterized with low vulnerability. They occupy $10 \%$ of the study area notably at Batoke (500 $\mathrm{m})$ and at Cape D ebundscha (3 km) (Fig. 3a).

Very high vulnerability to coastal erosion in terms of adjacent land use occurred in the built-up areas. Of the $35 \mathrm{~km}$ stretch of the coastline, 31.5 $\mathrm{km}(73.7 \%)$ is of very high vulnerability to coastal erosion (Fig. 3b). High vulnerability areas corresponded to agricultural land and plantations.

Moving from Batoke to Idenua, existing protection measures are in the form of walls and embankments (Fig. 3c). This thus leaves the highway, the settlements and other land uses very vulnerable to coastal erosion. Areas at the West Coast where protection measures had been put in place, had moderate vulnerability to coastal erosion but covered just $1.7 \mathrm{~km} \mathrm{(4.9 \% )} \mathrm{of} \mathrm{the}$ study area with the remaining $33.3 \mathrm{~km}(95.1 \%)$ characterized by very high vulnerability (Fig. 3c).

Taking all the variables into consideration, no zone in the West Coast was classified under very low vulnerability mainly because of the highly ranked adjacent land uses, which are mainly settlements, road infrastructure, and agricultural land (Fig. 4). Two hot spots for coastal erosion were identified corresponding to the $1 \mathrm{~km}$ segment of the coastline at DFP (Fig. 4) and $1.5 \mathrm{~km}$ segment at Idenau Beach. The vulnerability of the West Coast is equally further heightened by the general absence of coastal protection.

\subsection{Land cover/ land use changes observed in the West Coast and DFP}

A change in water cover by $22.85 \mathrm{~km}^{2}$ between 1986 and 2017 was obtained (Fig. 5a). The increasing extent of water cover could be attributed to factors like sea level rise and coastal erosion given that the geomorphologic and tidal factors remains highly unchanged. Also, the change in water cover though majorly caused by sea encroachment, has an insignificant proportion (< $00.5 \%$ ) that is attributed for by the few inland waters. With the extent of annual coastal change especially after 2014 (Table 4) at the West Coast, it is reasonable to state that in a year, the West Coast losses > $100 \mathrm{~m}^{2}$ of land to coastal erosion 
perceived more in zones with high levels of vulnerability such as: Batoke Beach, Seme Beach, DFP and Idenau Beach (Fig. 5a). Over $34 \%$ of the respondents in DFP cited the presence of new migrants in the community who were mostly civil servants and businesspersons. Their presence is synonymous to the construction of new houses at DFP on higher ground (Fig. 5b).
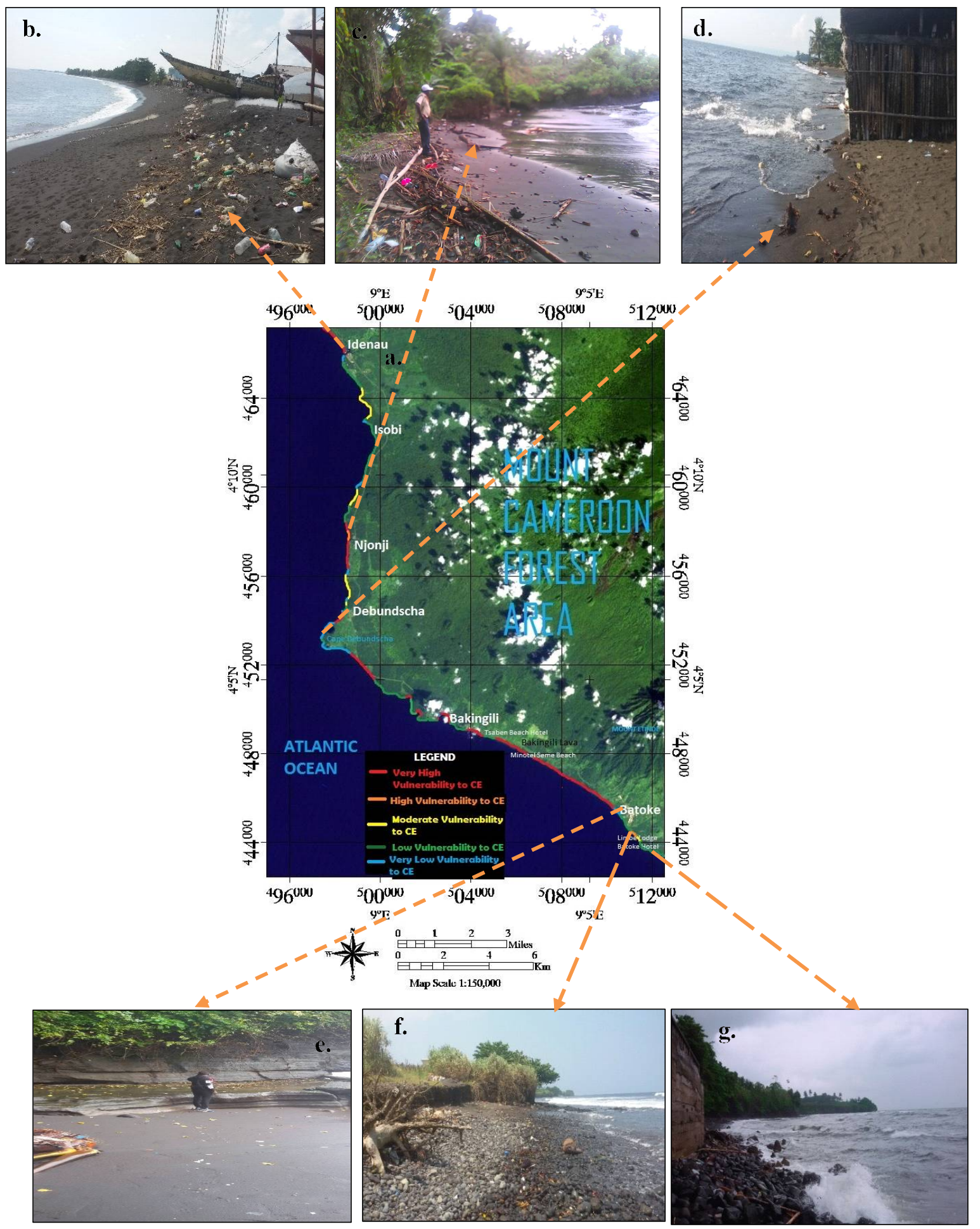

Fig. 2. Map and photographs showing a. level of vulnerability in the West Coast, b \& $\mathbf{c}$. sandy beaches at Idenua and Njonji respectively, d. beach at D ebundscha Fishing Port, e. Batoke rocky cliff, f. Batoke cobble beach, and g. ash + pebble cliff at Batoke 


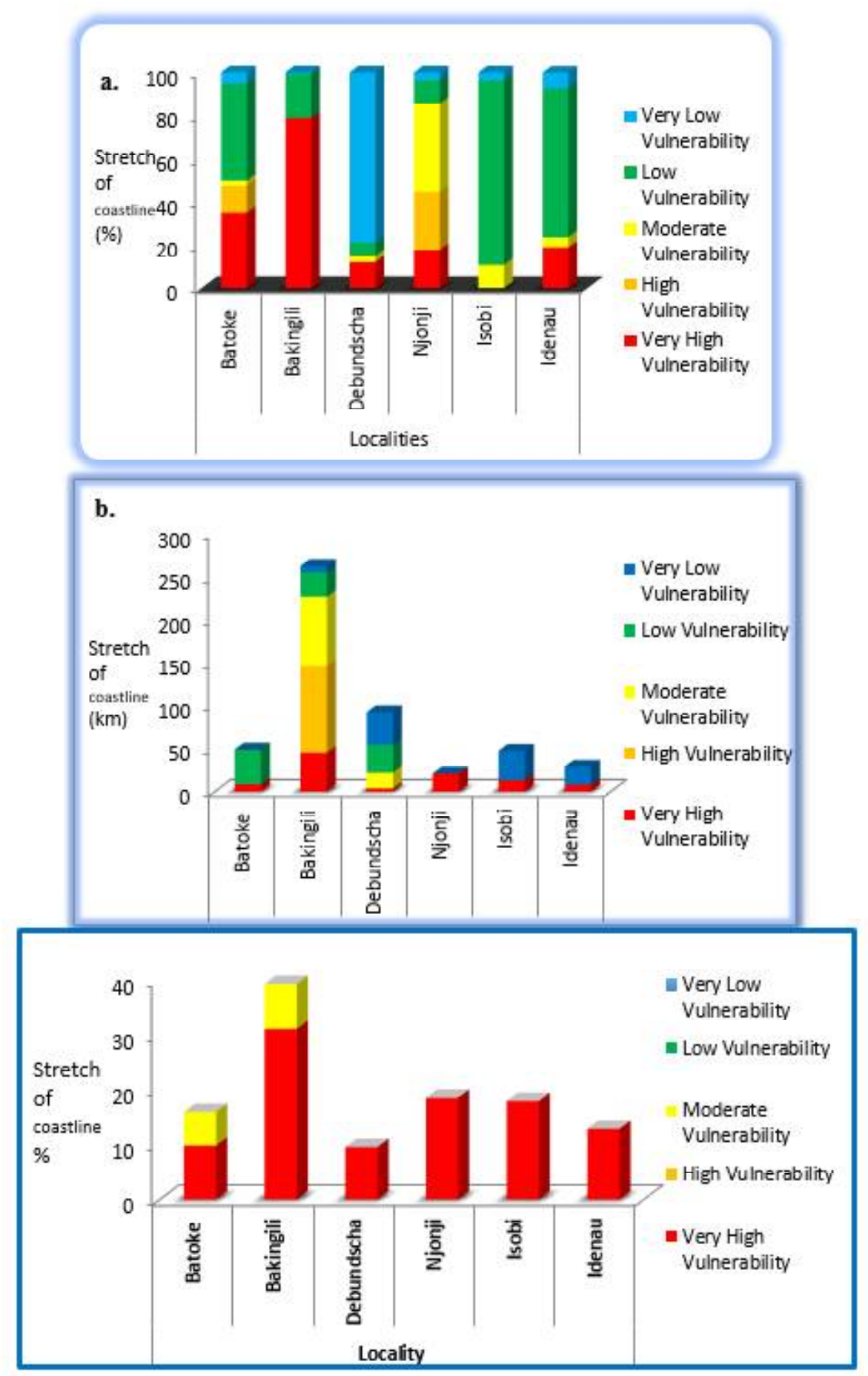

Fig 3: Distribution of levels of vulnerability in the different localites in the West Coast in terms of a. rock type (Geomorphology), b. adjacent land use and c. Coastal Protection 


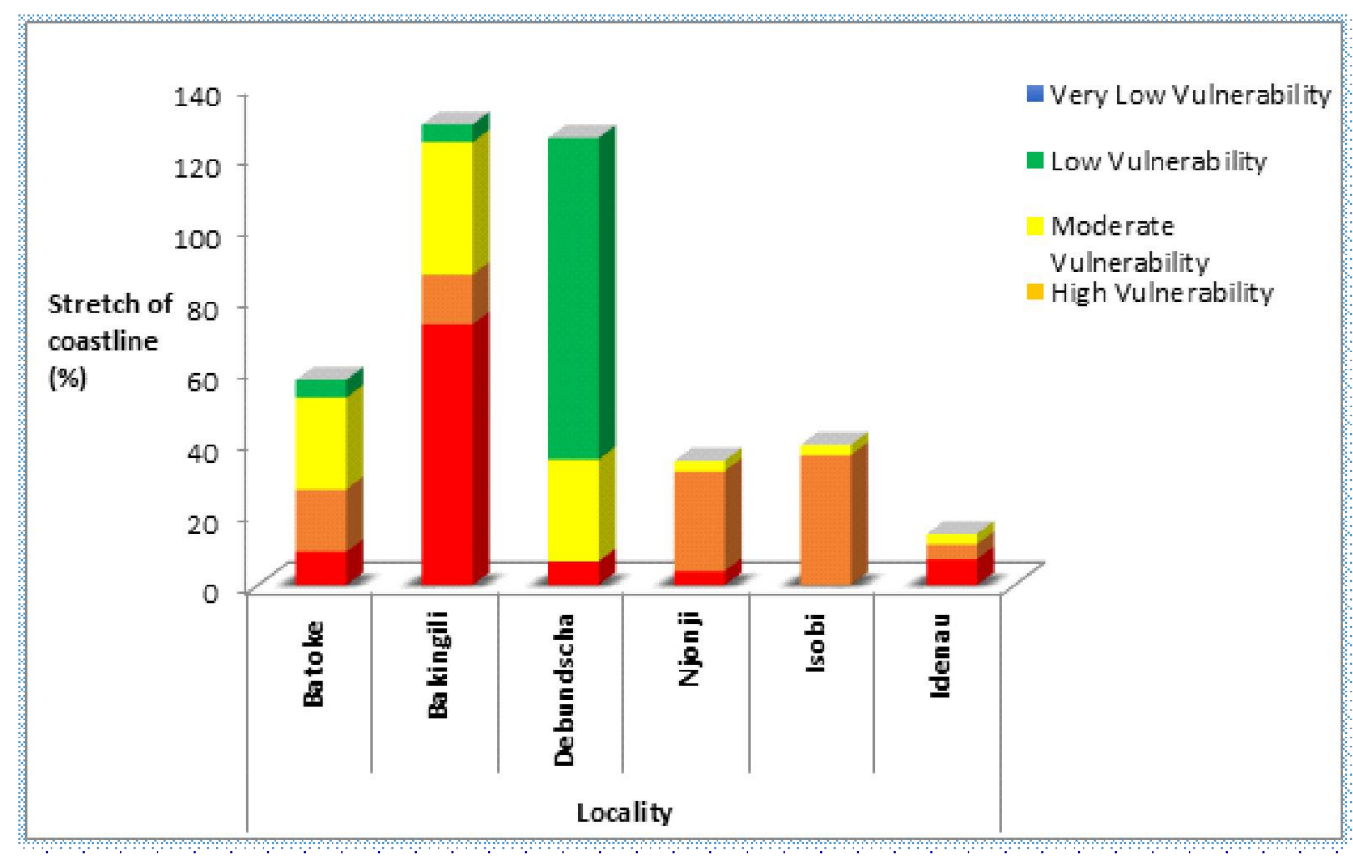

Fig. 4: Absolute Vulnerability Ranking of West Coast to Coastal Erosion in terms of rock type, adjacent landuse and coastal protection combined.

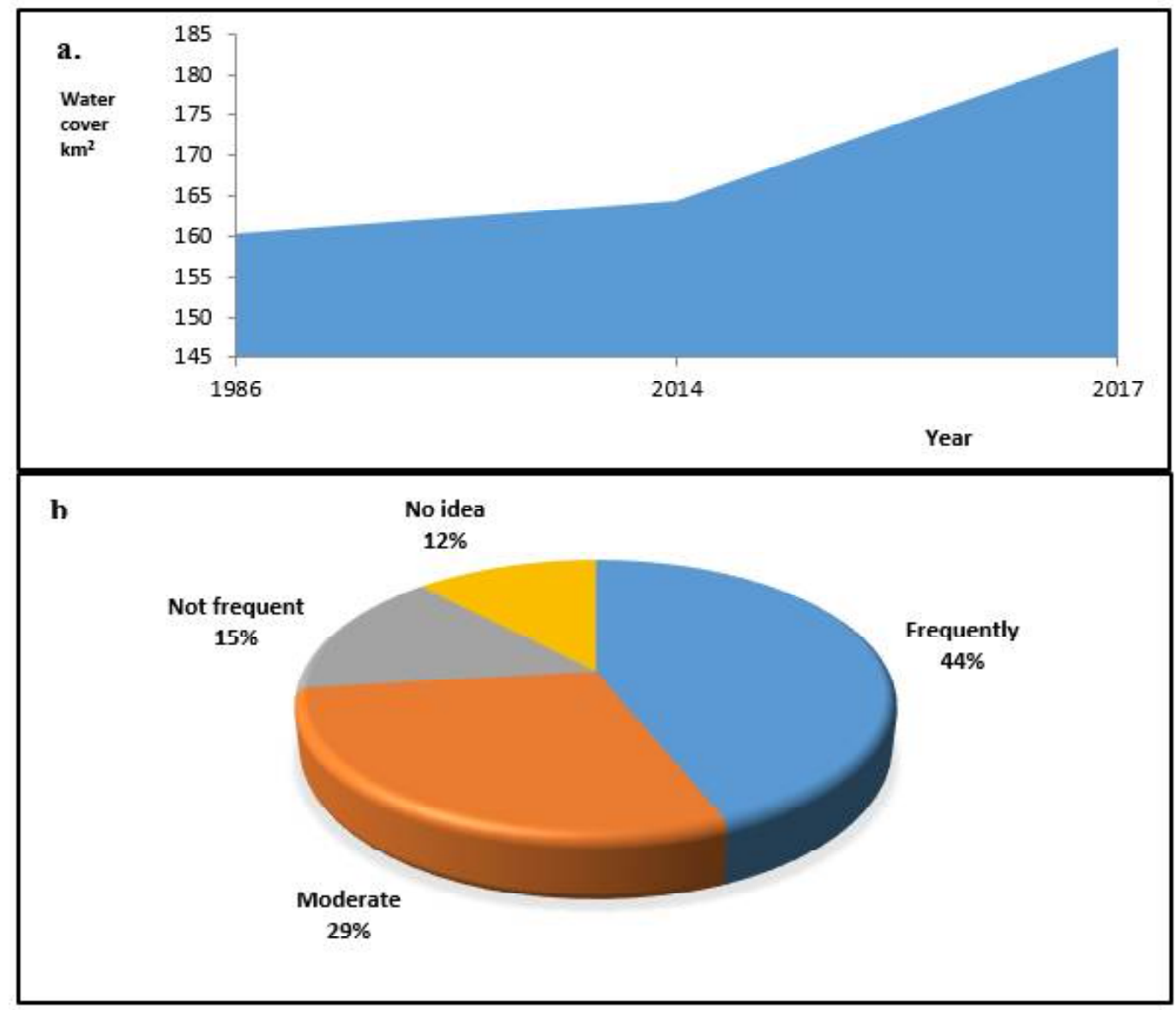

Fig 5: Land cover / landuse changes showing a. surface water change at the West Coast between 1986 to 2017 and $\mathbf{b}$. perception on the construction of new houses at DFP. 
Table 4: Changes in Water cover for West Coast between 1986 and 2017

\begin{tabular}{|c|c|c|c|c|c|c|c|c|c|c|c|}
\hline \multicolumn{3}{|c|}{$\begin{array}{c}\text { Water cover for different } \\
\text { years }\end{array}$} & \multicolumn{9}{|c|}{ Changes in Surface area, annual changes and \% changes } \\
\hline \multirow[b]{2}{*}{$\begin{array}{r}1986 \\
\left(\mathrm{~km}^{2}\right)\end{array}$} & \multirow[b]{2}{*}{$\begin{array}{r}2014 \\
\left(\mathrm{~km}^{2}\right)\end{array}$} & \multirow[b]{2}{*}{$\begin{array}{c}2017 \\
\left(\mathrm{~km}^{2}\right)\end{array}$} & \multicolumn{3}{|c|}{ 1986-2014 } & \multicolumn{3}{|c|}{$2014-2017$} & \multicolumn{3}{|c|}{ 1986-2017 } \\
\hline & & & $\begin{array}{c}\text { Total } \\
\text { change } \\
\text { in }\left(\mathrm{km}^{2}\right)\end{array}$ & $\begin{array}{l}\text { Annual } \\
\text { change } \\
\left(\mathrm{km}^{2} / \mathrm{yr}\right)\end{array}$ & $\%$ & $\begin{array}{c}\text { Total } \\
\text { change } \\
\text { in }\left(\mathrm{km}^{2}\right)\end{array}$ & $\begin{array}{l}\text { Annual } \\
\text { change } \\
\left(\mathrm{km}^{2} / \mathrm{yr}\right)\end{array}$ & $\%$ & $\begin{array}{c}\text { Total } \\
\text { change in } \\
\left(\mathrm{km}^{2}\right)\end{array}$ & $\begin{array}{c}\text { Annual } \\
\text { change } \\
\left(\mathrm{km}^{2} / \mathrm{yr}\right)\end{array}$ & $\%$ \\
\hline 160.43 & 164.38 & 183.27 & 3.96 & 0.14 & 0.09 & 18.89 & 6.30 & 3.83 & 22.85 & 0.74 & 0.40 \\
\hline
\end{tabular}

Further landcover changes from satellite images highlighted the following findings at the West Coast. For montane forest, $56 \%$ of the surface area had changed between 2000 and 2018 giving a net positive change of $1.24 \mathrm{~km}^{2}$ (Table 5; Fig. $6 a b)$. This positive increase is tied to the fact that Mount Cameroon forest is now classified as a reserve, thus less logging is being carried out on it. This fact also applies to the sub-montane and lowland forest which all experienced net increases (Table 5). Most of the older lava flows (e.g. 1922 lava), have already become vegetated. The observed decrease $\left(-24.25 \mathrm{~km}^{2}\right)$ in plantations (Table 5), is associated to a corresponding increase in farmland and settlement (Fig. 6b). Settlement increase is attributed to population increase. A net decrease of water bodies $\left(-0.54 \mathrm{~km}^{2}\right)$ could be attributed to the period when these images were obtained (i.e. D ecember (2000) and January (2018)) which represent the dry season period. Mt. Cameroon has seasonal streams/ springs, which dry off during the dry season.

Table 5: Statistics of Land-cover changes that have taken place in the Idenau Municipality between 2000 and 2018

\begin{tabular}{lllll}
\hline Land-cover Classes & \multicolumn{2}{c}{ Years } & \multicolumn{2}{l}{ Changes detected: 2000 to 2018 } \\
& 2000 & 2018 & \\
\cline { 2 - 5 } & $\begin{array}{l}\text { Surface Area covered } \\
\left(\mathrm{km}^{2}\right)\end{array}$ & $\begin{array}{l}\text { Surface Area } \\
\text { covered }\left(\mathrm{km}^{2}\right)\end{array}$ & $\begin{array}{l}\text { Percentage Change } \\
(\%)\end{array}$ & $\begin{array}{l}\text { Net change obtained } \\
\left(\mathrm{km}^{2}\right)\end{array}$ \\
\hline Montane Forest & 9.79 & 11.03 & 56.77 & 1.24 \\
Sub-Montane Forest & 8.93 & 22.16 & 45.55 & 13.23 \\
Lowland Forest & 25.55 & 28.30 & 89.19 & 2.74 \\
Plantations & 39.43 & 15.18 & 87.76 & -24.25 \\
Settlement/ Agric. Land & 4.87 & 31.39 & 62.08 & 26.44 \\
Lava & 3.06 & 2.52 & 99.55 & -5.57 \\
Water Bodies & 7.58 & 2.01 & 96.82 & -0.54 \\
Cloud Cover & 30.13 & 10.55 & 99.88 & -19.58 \\
\hline
\end{tabular}




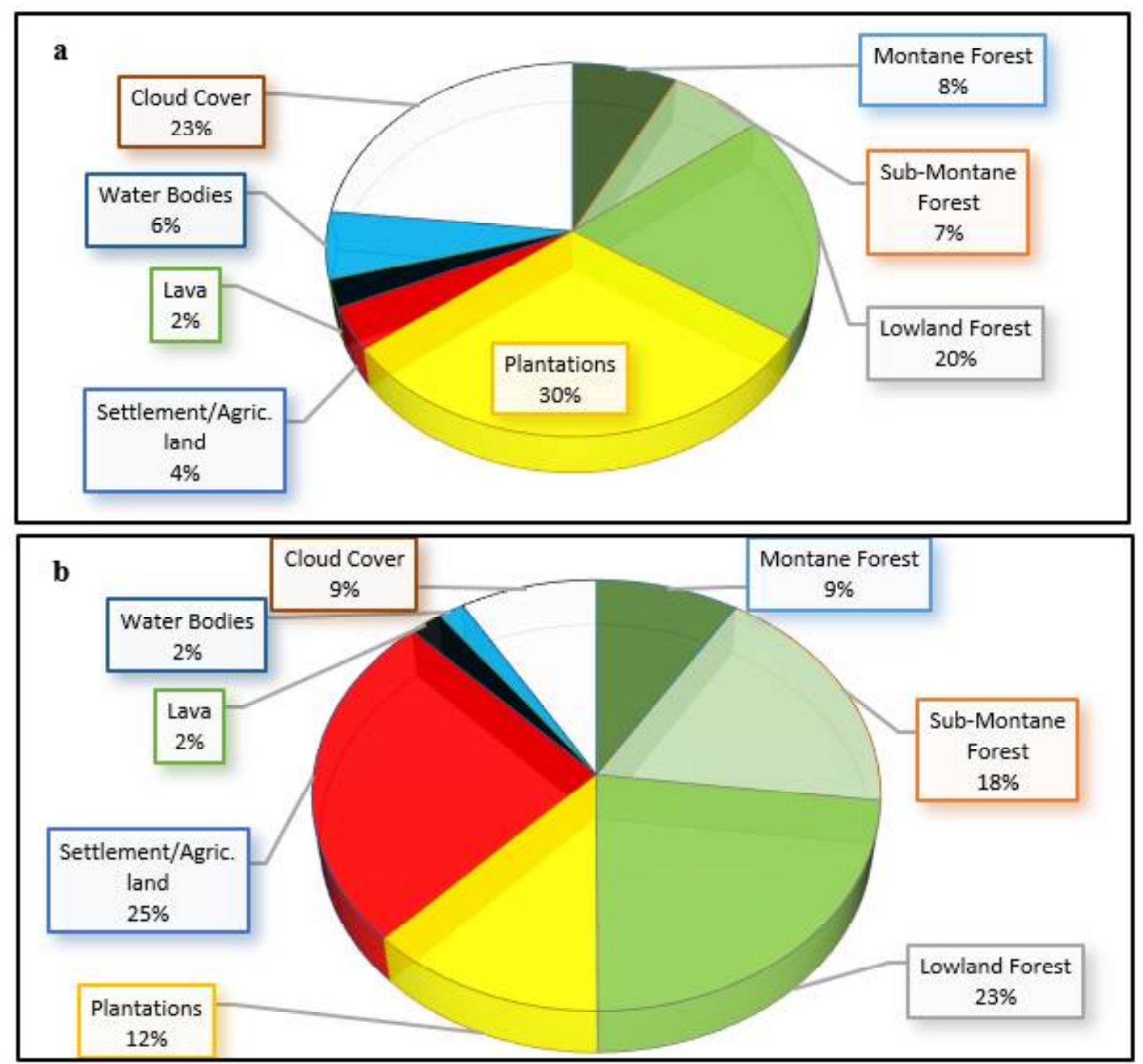

Fig. 6: Land cover changes showing total surface area (\%) covered by different land-covers at the West Coast in a. 2000 and b. 2018.

\subsection{Community perception on coastal erosion, floods and sea encroachment in the past 30 years}

At Batoke, DFP and Idenua, 50, 100 and $76 \%$ of the respondents respectively attested to have witnessed coastal changes in the past 30 years. These changes corresponded to 20, 100 and 50 $\mathrm{m}^{2}$ of eroded land in this period at these localities respectively (Fig. 7a). Based on the population who have witnessed coastal erosion, over $50 \%$ attested to the fact that coastal erosion is serious enough and warrants relocation.

Most of the respondents in DFP (75\%) were fully aware of the occurrence of floods and sea encroachment for the past 30 years in their community. The respondents defined coastal floods as heavy rainfall; a storm and as a large quantity of water (Fig. 7b). While sea encroachment was defined as: a rise in sea level; houses crumbling and loss of land (Fig. 7c). Their opinions on why these events occurred ranged from: punishments from the 'gods' (13\%) and natural phenomenon $(87 \%)$. For those who viewed it as natural events, over $70 \%$ of them attested to the fact that they are used to and can cope with it; while $<25 \%$ requested mitigation measures be put in place to address these hazards. 

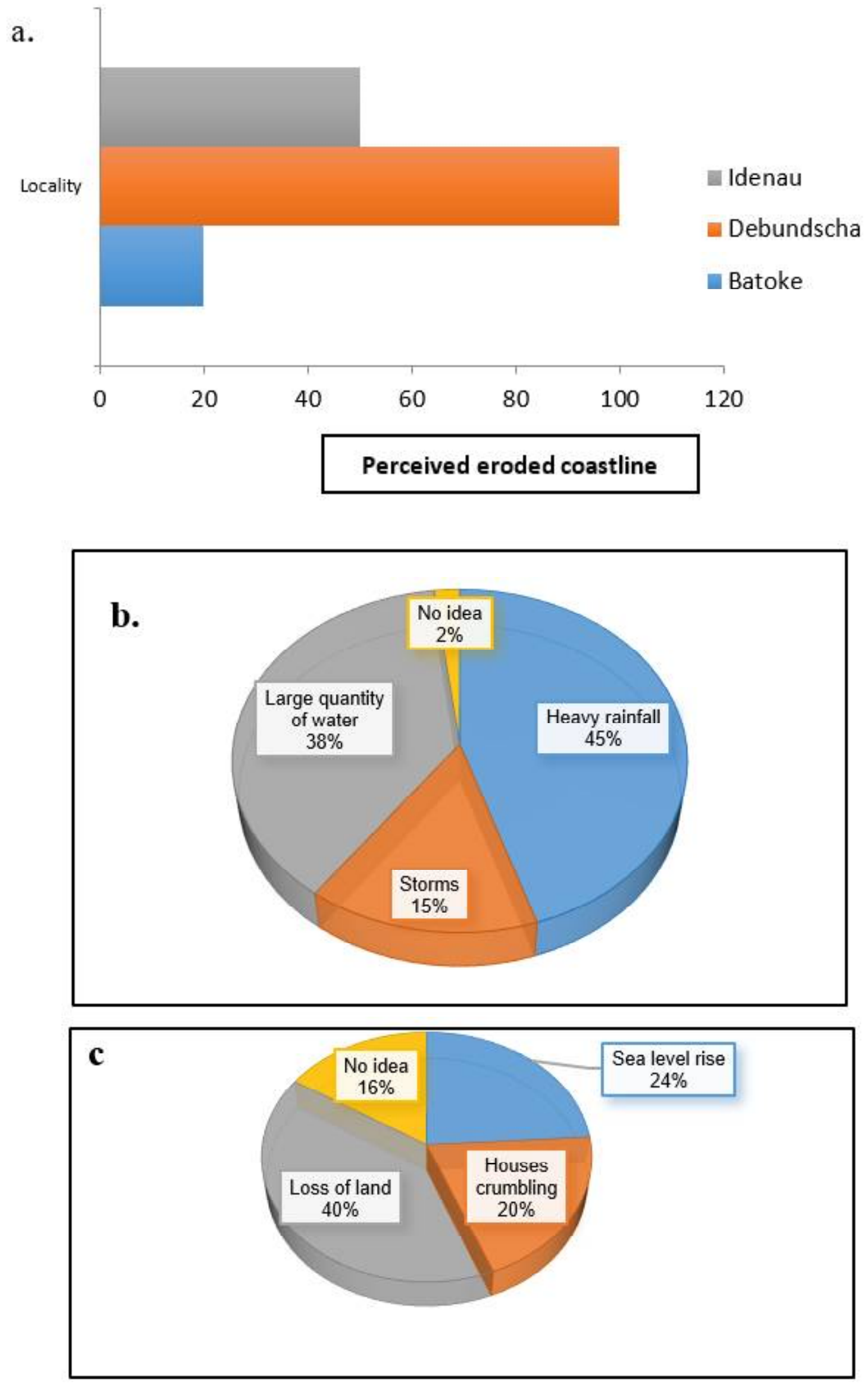

Fig. 7: G raphs showing a. perceived extent of coastal erosion at the West Coast, b. perceived knowledge on floods at DFP and c. perception of sea encroachment/ coastal erosion at DFP. 


\subsubsection{Physical, socio-economic and health effects of sea encroachment and floods in DFP}

At DFP, $31 \%$ of the respondents had experienced property damages in the past 30 years from sea encroachment and floods. The different physical damages included: reduction in crop yield; destruction of mangroves, livestock, embankments and settlement (Fig. 8a).

These hazards had resulted to deaths of family members linked to drowning during flooding events or during high tides. A total of $42 \%$ of the respondents, lost money or needed financial support due to damages caused by flood and sea encroachment on their property. Another group ( $26 \%$ ) were of the opinion that sea encroachment affects the fishing methods of fishermen, while, $27 \%$ talked of changes in land cultivation methods caused by sea encroachment.

D isease prevalence in DFP because of floods and sea encroachment included: malaria; typhoid; skin diseases; diarrhoea; stomach ache and dysentery (Fig. 8b). From these findings, malaria and abdominal disorders linked to poor water quality are the prevalent diseases in this community. The only potable spring in this community is usually polluted with saline water intrusion into the fresh water.

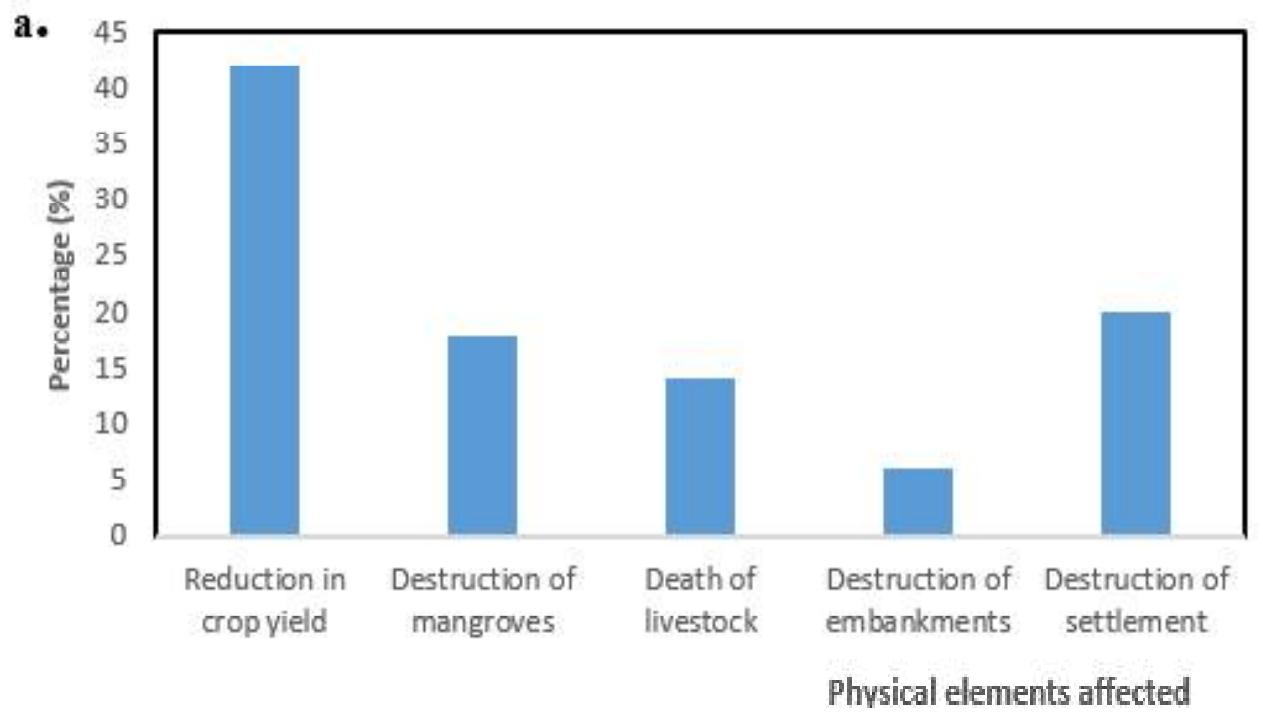

b.

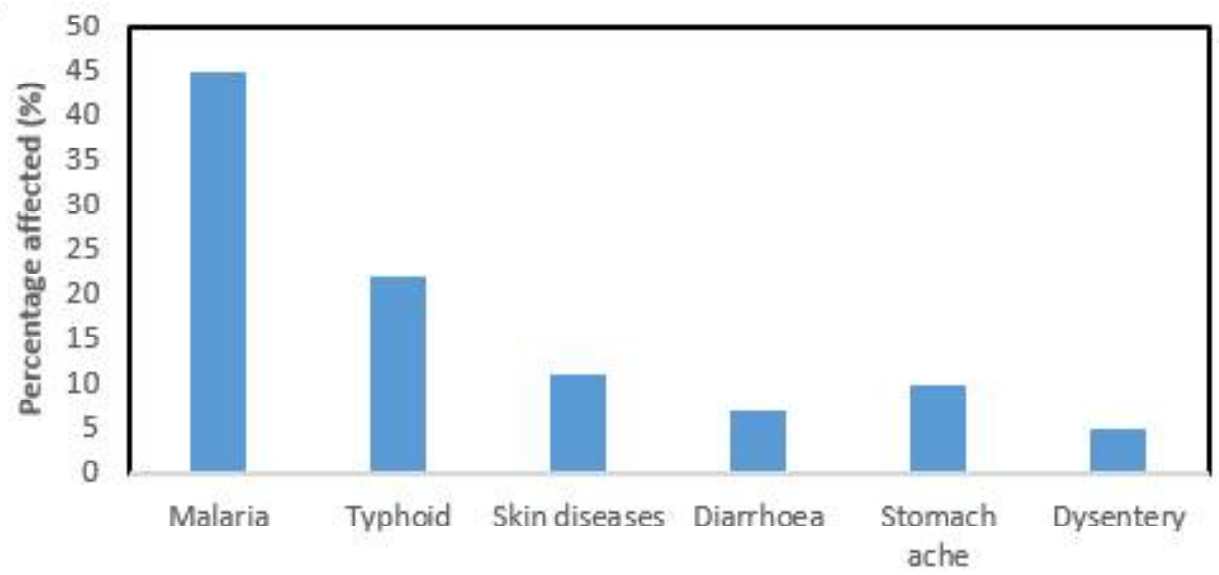

Diseases

Fig. 8: G raphs showing a. physical/ environmental elements affected by sea encroachment and coast erosion at DFP and $\mathbf{b}$. the resultant prevalent diseases at DFP. 


\subsubsection{Coping strategies used at the West Coast and FP community against coastal erosion and sea encroachment}

The inhabitants at the West Coast have resorted more to adaptation strategies (Fig. 9) than counteracting coastal erosion. These measures include: sandbags; embankments; elevation of foundations and building on higher grounds; beach nourishment, fishermen anchor their boats in lagoon, wharf and estuary away from the eroded coastline; temporary usage of some houses and shops during specific periods of the day and year (Fig. 9). For those who had put in place these mitigation measures in the DFP, $75 \%$ of the respondents were of the opinion that, these strategies have not been effective; $18 \%$ cited moderately effective and $7 \%$ said it has been very effective. The results showed that the coping strategies put in place were not effective against floods and sea encroachment.
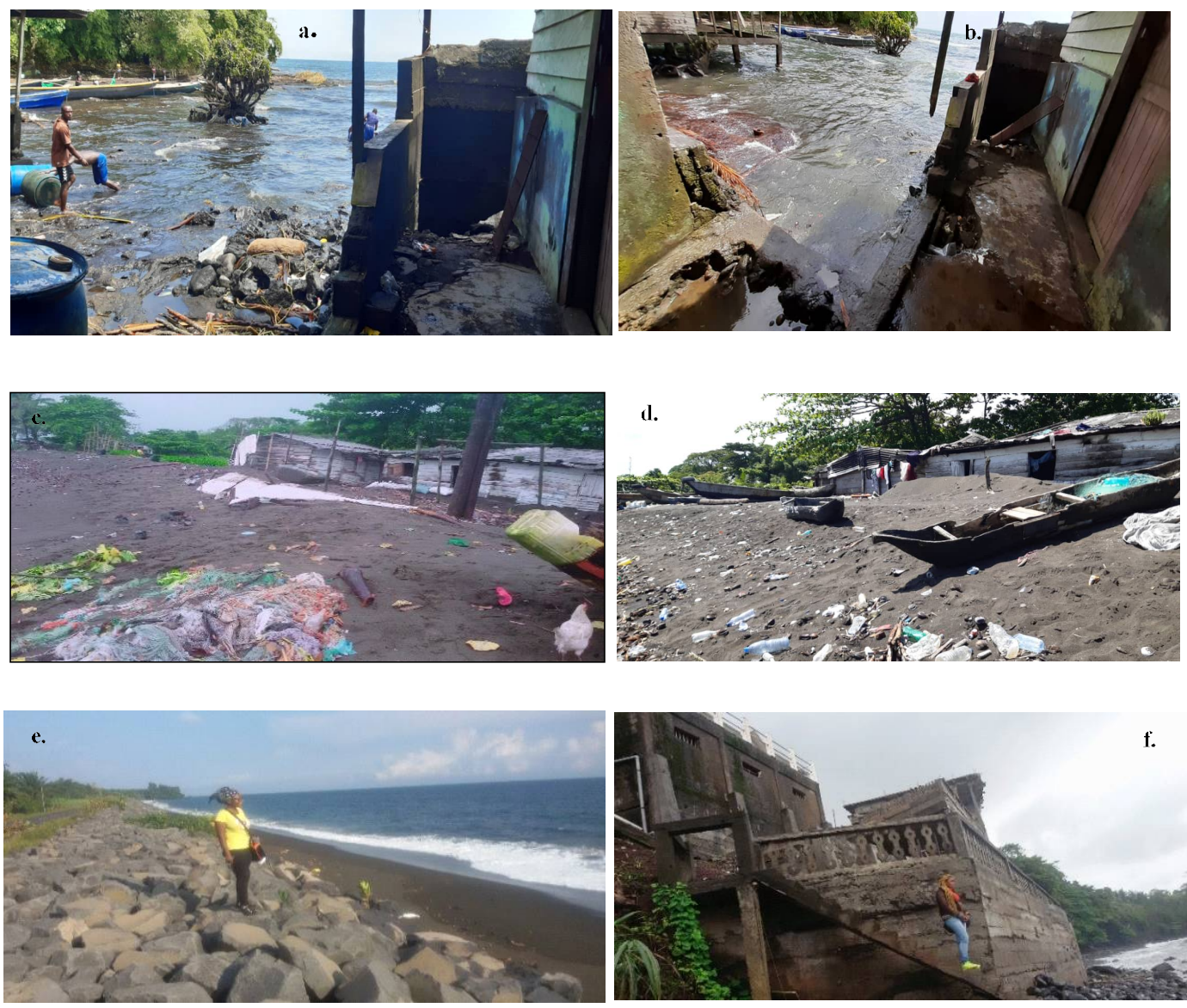

Fig. 9: Coastal protection measures implemented at the West Coast showing a \& b. embankments at DFP, $\mathbf{c} \& \mathbf{d}$. use of sand bags at DFP, e. rock embankment protecting the highway at the West Coast and f. seawall (embankment) at Batoke. 


\subsection{Cost-Benefit Analysis for Mitigation}

Adaptation strategies were assessed based on social, technical, administrative, economic, and environmental benefits and costs. The options examined for the West Coast were: vegetative cover, beach nourishment, shoreline protection and elevating structures or relocation using multicriteria analysis (Table 6). Vegetative cover was ranked as the highest (1) suggested option. This option is inexpensive, accepted by the public and requires low-maintenance. Beach nourishment came second. This option is temporary and should be done periodically. Shoreline protection was the third option, though a more permanent solution, is very costly and disrupts natural coastal and marine processes. Elevation of structures ranked fourth, however it is expensive. Relocation is the most viable option for coastal erosion since it has little or no impact on the environment, however, the cost can be prohibitive.

Table 6: Overall Adaptation Cost-Benefit

\begin{tabular}{|c|c|c|c|c|c|c|}
\hline $\begin{array}{l}\text { Adaptation } \\
\text { Option }\end{array}$ & Benefits & $\begin{array}{l}\text { Benefits } \\
\text { High=4 } \\
\text { Medium =3 } \\
\text { Low }=2 \\
\text { Very Low=1 }\end{array}$ & Costs & $\begin{array}{l}\text { Costs } \\
\text { High=4 } \\
\text { Medium =3 } \\
\text { Low =2 } \\
\text { Very Low =1 }\end{array}$ & $\begin{array}{l}\text { Ratio } \\
\text { Benefits/ Costs }\end{array}$ & Ranl \\
\hline $\begin{array}{l}\text { V egetative } \\
\text { cover }\end{array}$ & $\begin{array}{l}\text { Time saving and } \\
\text { reduction in labour } \\
\text { requirements. } \\
\text { Reduces sediment loss. } \\
\text { Easy to implement and } \\
\text { support. } \\
\text { Locals can be trained to } \\
\text { implement and maintain }\end{array}$ & 3.75 & $\begin{array}{l}\text { Reduction of costs such as } \\
\text { machinery operating costs, } \\
\text { maintenance, and labor cost. } \\
\text { Less sandy area for } \\
\text { beachgoers. } \\
\text { One-time implementation } \\
\text { with continuous maintenance }\end{array}$ & 1 & 3.75 & 1 \\
\hline $\begin{array}{l}\text { Beach } \\
\text { Nourishment }\end{array}$ & $\begin{array}{l}\text { Reduction in risk of } \\
\text { property loss } \\
\text { Preserve beach } \\
\text { conditions with minimal } \\
\text { impact }\end{array}$ & 3.5 & $\begin{array}{l}\text { Impoundment and closures } \\
\text { during nourishment. } \\
\text { Temporary disruption to } \\
\text { beachgoers and marine life. } \\
\text { Periodic implementation and } \\
\text { monitoring }\end{array}$ & 1.75 & 2 & 2 \\
\hline $\begin{array}{l}\text { Shoreline } \\
\text { Protection }\end{array}$ & $\begin{array}{l}\text { Reduction in risk of } \\
\text { property loss } \\
\text { Can be constructed in } \\
\text { small areas. } \\
\text { Protects homeowners' } \\
\text { properties and other } \\
\text { infrastructures }\end{array}$ & 2.25 & $\begin{array}{l}\text { Cost dependent on materials } \\
\text { and type. } \\
\text { Potential harm to recreational } \\
\text { activities. } \\
\text { Temporary disruption to during } \\
\text { marine and } \\
\text { development } \\
\text { maintenance. } \\
\text { Long term process for } \\
\text { regulations. } \\
\text { Periodic to one-time } \\
\text { implementation and } \\
\text { maintenance }\end{array}$ & 2.5 & 0.9 & 3 \\
\hline $\begin{array}{l}\text { Elevation or } \\
\text { Relocation }\end{array}$ & $\begin{array}{l}\text { Reduces damages to } \\
\text { buildings. } \\
\text { Moving away causes little } \\
\text { or no negative } \\
\text { environmental effects. } \\
\text { Stakeholders have } \\
\text { ownership over final } \\
\text { decisions }\end{array}$ & 2.5 & $\begin{array}{l}\text { Varies in cost dependent on } \\
\text { structure and size. } \\
\text { Relocation is often } \\
\text { impractical. } \\
\text { Temporary disruption during } \\
\text { development and process of } \\
\text { moving. } \\
\text { Continuous to one-time event }\end{array}$ & 3.5 & 0.71 & 4 \\
\hline
\end{tabular}




\subsection{Discussion}

\subsection{The level of vulnerability of the West Coast to coastal E rosion}

This study has identified two major hotspots of coastal erosion: DFP and Idenau Beach (Fig. 2). This result is similar to that obtained by $\mathrm{O}$ uabo et al. (2018) at the Kribi coast and Li and Pgrni (2017) in studies carried out at the coast in Southern Sri Lanka. Li and Pgrni (2017) identified the localities of Kahawa, Hikkaduwa and Galle as coastal erosion hotspots. Difference in the erodibility of different geomorphological features played the greatest role in determining the vulnerability of the West Coast to coastal erosion, similar to what was established by Alexandrakis (2008) at the Hellenic Aegean coastline.

Temperatures over Cameroon have been on the increase since 1930 (Ayonghe, 2001). Molua and Lambi (2006) registered a net temperature increase of $0.95^{\circ} \mathrm{C}$ between 1930 and 1995. Increase in temperature affects ocean surface temperature, causing them to become warmer and expand, which leads to sea level rise. Average temperatures within Limbe and the West Coast have risen from $24^{\circ} \mathrm{C}$ (1986) to $27^{\circ} \mathrm{C}$ (2016) (Tanyui, 2020). The increase sea encroachment and coastal erosion at the West Coast is attributed to changes in climate in the last 30 years as observed by Tanyui (2020). A reas along coastlines become subject to flooding caused by subsidence and rising sea level which leads to the encroachment of the sea on to the land.

\subsection{Landcover, physical, socio-economic and health impacts of coastal floods and sea encroachment in DFP}

One of the major physical damages caused by sea encroachment at D ebundscha is coastal erosion, which has led to the engulfment of a substantial portion of the settlement area. A respondent that had lived in the area for 28 years, recounted that in the past houses used to be built with Indian bamboos and straw. This shifted to wood 10 years ago as the water started advancing. The Chief of D ebundscha acknowledged that settlement in DFP has changed positions due to coastal erosion caused by sea encroachment. This issue of land degradation by sea encroachment is not limited to Debundscha and the West Coast area. Studies carried out by Ly (1980) in the coastal area of G hana, showed that the shoreline of Ada Foah has been experiencing coastal erosion for more than seven decades characterised with damaging effects like that of Debundscha. Residents of Ada Foah are faced with the destruction of private homes, loss of coastal land and biodiversity (Kusimi and Dika, 2012). In Debundscha, $65 \%$ of the respondents have lost houses, crops, businesses and pieces of land because of sea encroachment and strong waves.

Almagro-Blanco's (2011) studies in the Philippines revealed that water from the sea reaches as high as the knee level in spots as far off as 50-60 m away from the shoreline. This is a replica of what is presently happening at the DFP that has led to the relocation of most settlements that were by the seashore, to distances of $\geq 50 \mathrm{~m}$ away at a site provided for by the Idenua Council. The alteration of settlement land by sea advancement in southern Tamil Nadu, India, has also resulted to resettlement of the community (Barange $\notin a l$., 2018). All of these issues have financial implications which affects the living standards of the population in this area.

Affected economic activities at the West Coast include fishing, commerce and settlement. This finding is similar to that reported by the CSE (2010) for Senegal where they reported that the thin strip of coastline in the city of St Louis is fast eroding under coastal forces. CSE (2010) further explained that, the beach where the Senegalese national soccer team had practiced some years back no longer exists with hoteling and other coastal-based services and activities highly weakened. Similarly, Candice \& al. (2014) also cited that in Columbus Bay on Trinidad Island, 
coastal erosion has resulted in a reduction in beach amenity, loss of valuable agricultural land, critical mangrove habitats and damage to infrastructure. Despite the adverse impacts of sea encroachment on this community, landcover analyses for the last 18 years shows that settlement is rather increasing in the area, which has led to a corresponding increase in farmlands. Increase in settlement has been facilitated by the reduction of land formerly used for plantation agriculture. In 2017, the government allocated plantation land previously owned by the Cameroon Development Corporation (CDC) to the Debundscha population at affordable prices. Shrestha (2019) observed an increase in built-up areas when analyzing landcover changes in the Pampanga River basin of the Philippines for a period of 20 years. This increase could be attributed to the vast amount of resources offered by coastal ecosystems.

The most prevalent diseases in the DFP community are malaria, skin rashes and abdominal diseases. The cause of these diseases is linked to flooding that leaves behind standing water which serves as breeding grounds for mosquitoes and the contamination of their potable water source (a spring) by sea water. A study carried out by Addo $\&$ al. (2011) in the coastal area of G hana also cited the prevalence of malaria, skin rashes and abdominal diseases in these communities.

\subsection{Community knowledge on sea encroachment and coastal erosion in the past 30 years}

Most of the respondents at DFP were knowledgeable to the fact climate has changed in the past 30 years and one of its impacts was a rise in sea level. Similar studies carried out by Mello \& al. (2012); Viegas (2014), Medeiros \& al. (2014) and Hussein $\notin$ al. (2019) demonstrated that $92.9 \%$ of the artisanal fishermen in their study sites recognized that the climate is changing, through perceptions of changes in temperature or precipitation variation, and sea level change. A small percentage (13\%) of the population in DFP believed that these events are spiritual and punishments from the anger of the gods 'Nyango ma mona' which causes the water to increase and rise. The association of sea encroachment or floods to the anger of 'gods' is not a belief restricted to the population at the West Coast. O luseyi and Oloukoi (2013), revealed that the Ijaws (local population along the Nigerian coastline) believe that water spirits can be angered and they exhibit it by inundating and flooding of coastal communities.

D omingos (2016) identified coastal erosion as the main coastal change event at the Mozambique coast (169 hectares). Findings from this research shows a steady rise in the rate of coastal erosion by more than $100 \mathrm{~m}^{2}$ yearly, but according to Domingos (2016), coastal erosion along Mozambique's coast fluctuates. Thang (2017) observed that though $4.43 \mathrm{~km}^{2}$ of land was eroded during the previous 40 years in the Western Menkong River in Vietnam the coastline is now fairly stable. This contradicts with findings from this study, which identified that the rate of coastal erosion is steadily rising.

\subsection{Evaluating the mitigation strategies used by the local community to cope with these hazards}

A handful of those living in the DFP cited the use of sandbags, embankments, raised foundations to build elevated houses, building on higher grounds as some of the mitigation measures used against sea water encroachment (Fig. 9). However, some of these measures had proven ineffective as the sea still destroyed their property. This is because of poor town planning in DFP, lack of drainage systems, no motoroble roads within the village. Effective embankments in such an area will need to adopt the proposed engineering-biological method of Parlichev D. and Parlichev G. (2003), which performs five basic functions: wave breaking, beach generation, 
biological, ecological and recreational. However, this is costly.

Cost benefit analysis performed at the West Coast in its adaptation to coastal erosion was also proposed for Sunset Beach in Hawaii (Marchant, 2017). However, in comparison to Sunset Beach, the West Coast has weak adaptation potentials. Consequently, some adaptation options proposed to Sunset Beach are not valid for the West Coast. CSE (2010) recommended the involvement of local communities for effective adaptation to sea level rise and its impacts in Senegal.

In this study, the adaptation option of coastal protection was ranked third because of its expensive nature and its interrupting effect on coastal natural processes. Whereas, vegetation cover and beach nourishment were ranked first and second respectively. Contrarily, the Vineyard Conservation Society (VCS, 2018), ranked coastal protection especially coastal armouring (the practice of using physical structures such as seawalls to protect shorelines from coastal erosion) highly as an adaptation option. Despite acknowledging the adverse effects of especially hard coastal amouring on the environment and its high cost, they justified that the option protects invaluable assets and resources immediate to it. They added that without the seawall, the sand beach would be located far inland today and the parking lot gone, possibly leading to loss of access in the Oak Bluffs Harbour in the US. Construction of the seawall has according to VCS (2018), therefore bought time to enjoy a valuable town resource.

\subsection{Conclusions}

This research aimed to assess and evaluate the physical vulnerability and community perception of the population at the West Coast on sea encroachment and coastal erosion. Based on the findings from this study, we recommend that the local council should build embankments along the coast; the available ones are limited and not everyone has the capacity to build one. Also, we recommend the construction of good drainage systems, roads, bridges and proper town planning. The only available bridge is not strong enough to support heavy-duty construction vehicles. Unplanned houses also block waterways. The provision of potable pipe-borne water will go a long way to reduce the frequency of water-borne diseases suffered by these communities. The implementation of these recommendations would reduce the impacts of coastal erosion and sea encroachment in these communities.

\subsection{Acknowledgements}

The authors wish to acknowledge logistic support from the University of Buea, Cameroon and financial support from the USAID grant through the PERIPERI U Consortium of UBuea award No. AID-OFDA-G-16-00115.

\subsection{References}

Addo, A., Kwasi, Walkden, Mike, Mills, J.P. (2008). Detection, measurement and prediction of shoreline recession in Accra, Ghana. ISPRS Journal of Photogrammetry and Remote Sensing 63, 543-558. 10.1016/ j.isprsjprs.2008.04.001.

Addo, K.A., Larbi, L., Amisigo, B., O fori-D anson, P.K. (2011). Impacts of Coastal Inundation Due to Climate Change in a CLUSTER of Urban Coastal Communities in Ghana, West Africa. Rente Sensing3(9), 2029-2050; https:/ / doi.org/ 10.3390/ rs3092029.

Alexandrakis, G., Kardista, S., Poulos, E. (2008). An Assessment of the Vulnerabilty to Erosion of the Coastal Zone Due to Potential Rise of Sea Level: The Case of the Hellenic Coast. Environmental Systems III, 3-6. 
Almagro-Blanco, L.A. (2011). Knowledge, Power Relations and Resource Control as Drivers of Local Adaptation Strategies to Sea Level Rise: The experience of two small island communities in Central Philippines. A Research Paper presented in partial fulfillment of the requirements for obtaining the degree of Masters of Arts in Development Studies (Environment and Sustainable Development; ESD) at the Hague, Netherlands, 44pp.

Arnset, A., D angendorf, S., Jensen, J., Talke, S., Bender, J., Pattiaratchi, C. (2017). Sea-level rise induced amplification of coastal protection design heights. Nature Scientific Reports 7, 40171.

Asangwe, K. (2007). Economic Benefits of Hydrography, the Implications of Rising Sea Level on the Coastal Lowlands of Cameroon, Strategic Integration of Surveying Services pp 46. Hong Kong.

Ayonghe, S.N. (2001). A quantitative evaluation of global warming and precipitation in Cameroon from 1930 to 1995 and projections to 2060: Effects on environment and water resources. In: Lambi, C.M. (ed.), Environmental Issues: Problems and Prospects, Bamenda: Unique Printers.

Ayyam, V., Palanivel S., Chandrakasan S. (2019). Coastal Ecosystems of the TropicsAdaptive Management. ISBN 978-981-138925-2; https:/ / doi.org/ 10.1007/ 978-981-138926-9.

Ayyam, V., Palanivel, S., Chandrakasan, S. (2019). Coastal Ecosystems of the TropicsAdaptive Management. https:/ / www.researchgate.net/publication.
Barange, M., Bahri, T., Beveridge, M.C.M., Cochrane, K.L., Funge-Smith, S., Poulain, F., eds. (2018). Impacts of climate change on fisheries and aquaculture: synthesis of current knowledge, adaptation and mitigation options. FAO Fisheries and Aquaculture Technical Paper No. 627. Rome, FAO. $628 \mathrm{pp}$.

Bienfang, P., O ben, B., D eFelice, S., Moeller, P., Huncik, K., O ben, P., Toonen, R., DalyEngel, T., Bowen, B. (2008) Ciguatera: the detection of neurotoxins in carnivorous reef fish from the coast of Cameroon, West Africa, African Journal of Marine Science 30(3), 533-540, DOI: $\underline{10.2989 /}$ AJMS.2008.30.3.8.642.

Bird, E.C.F. (2008). Coastal geomorphology: An introduction. Second Edition, Wiley \& Sons, Inc New York, ISBN: 978-0-470-51729, 436pp.

Candice, L., A sha, S., Rameez, P.Junior, D. (2014). The Influence of Tidal Currents on Coastal Erosion in a Tropical Micro-Tidal Environment - the Case of Columbus Bay, Trinidad University of the West Indies, St A ugustine Campus, Trinidad and Tobago Global. Journal of Science Frontier Research 14, 2249-4626.

Centre de Suivi Ecologique (CSE) (2010). Adaptation to Coastal Erosion in Vulnerable Areas, Senegal, 2018 UNFCCC, New York.

Church, J. A., Clark, P. U., Cazenave, A., G regory, J. M., Jevrejeva, S., Levermann, A. (2013). "Sea level change" in Climate Change 2013: The Physical Science Basis. Contribution of Working Group I to the Fifth Assessment Report of the Intergovernmental Panel on Climate Change (eds) Stocker, T. F. D., Q in, G.-K., Plattner, M., Tignor, S. K., Allen, J., Boschung, A. Cambridge University Press, 1137-1216. 
Clark, J.C., Brabb, E.E. (1997). G eology of Point Reyes National Seashore and Vicinity, California: A Digital Database; Open - File Report 97-456.

D omingos, P.F.B. (2016). Characterization of Mozambique's Vulnerability to Coastal Erosion. A thesis submitted to obtain the Master of Science Degree in Environmental Engineering at TECNICO LISBAO, 94pp.

Pendleton, E.A., Thieler, E.R., Williams, S.J. (2005) Coastal Vulnerability Assessment of Golden Gate National Recreation Area to SeaLevel Rise, U.S. D epartment of the Interior U.S. Geological Survey.

Fagotto, M. (2016). West A frica Is Being Swallowed by the Sea. Encroaching waters off the coast of Togo, Ghana, Mauritania, and others are destroying homes, schools, fish, and a way of life. https:// m.facebook.com/ matteojournalist/. https:/ / foreignpolicy.com/ 2016/ 10/ 21/ westafrica-is-being-swallowed-by-the-sea-climatechange-ghana-benin/ .

Famara, D. (2015). Assessing and Adapting to Climate-Change Induced Sealevel Rise on the Southern Coastline of the Gambia, United Nations - Nippon Foundation of Japan Fellowship Programme- 2012-2013.

Hammar-Klose, E.S., Thieler, E.R. (2001). Coastal Vulnerability to Sea-Level Rise, a Preliminary D atabase for the U.S. Atlantic, Pacific, and Gulf of Mexico Coasts. U.S. Geological Survey, Digital Data Series, DD S-68.

Höffken, J., Vafeidis, A., MacPherson, L.R., Dangendorf, S. (2020). Effects of the Temporal Variability of Storm Surges on Coastal Flooding. Frontiers in Marine Science 7, doi.org/ 10.3389/ fmars.2020.00098.

Hussein, I., de Fátima Alves, M., Morgado, F. (2019) Artisanal Fishing and Climate Change:
The Case of Pemba, Mozambique. In: Leal Filho, W., Azul, A., Brandli, L., Ö zuyar, P., Wall T. (eds) Climate Action. Encyclopedia of the UN Sustainable Development Goals. Springer, Cham. https:// doi.org/ 10.1007/ 978-3-31971063-1 121-1.

Hussein, K., Alkaabi, K., G hebreyesus, D., Liaqat, M.U., Sharif, H.O. (2020). Land use/ land cover change along the Eastern Coast of the UAE and its impact on flooding risk. Geomatics, Natural Hazards and Risk 11 (1), 112-130.

Idenua Council D evelopment Plan (CD P, 2011).

IPCC, (Intergovernmental Panel on Climate Change. Response Strategies Working Group) (1991). The Seven Steps to the Assessment of the Vulnerability of Coastal Areas to Sea Level Rise, A Common Methodology. Bd. Revision 1, Cambridge University Press.

Joanna, C., Isabella, Z. (2012). Vulnerability to Climate Change of Mangroves: Assessment from Cameroon, Central Africa, School of G eography and Environmental Studies, University of Tasmania, Locked Bag 1376, Launceston 7250, Tasmania, Australia and Ministry of Environment and the Protection of Nature, MINEP, PB 320 Yaoundé, Cameroon.

Kometa, S.S. (2012). Ensuring Human Safety in the Disaster Prone Coastal Town of Limbe, Cameroon. Journal of Geography and Geology 4(2), 1916-9779, doi:10.5539/ jgg.v4n2p156 URL.

Kusimi, J.M., Dika, J.L. (2012). Sea erosion at Ada Foah: assessment of impacts and proposed mitigation measures. Natural Hazards 64 (2), $983-$ 997. https:// doi.org/ 10.1007/ s11069-012-02163. 
Li, L., Pgrni, P. (2017). Assessment of vulnerability for coastal erosion with GIS and AHP techniques case study: Southern coastline of Sri Lanka. Natural Resource Modeling e12146. 10.1111/ nrm.12146.

Luijendijk, A., Hagenaars, G., Ranasinghe,R., Baart, F., D onchyts, G., Aarninkhof, S. (2018). The State of the World's Beaches. Scientific Reports 8, 6641, doi: 10.1038/ s41598-01824630-6.

Ly, K. C. (1980). The role of the Akosombo D am on the Volta River in causing coastal erosion in Central and Eastern G hana (West Africa). Marine Geology 37, 323-332.

Marchant, M. (2017). Application of Coastal Vulnerability Index (CVI) on the Island of $\mathrm{O}$ ahu. A thesis submitted to the Global Environmental Science undergraduate Division in Partial fulfilment of the requirements for the Degree of Bachelor of Science in Global Environmental Science, 82pp.

Medeiros, E.C., Miola, B., Lima, R., Pantalena, A.F. (2014) Percepção Dos Pescadores Do Nordeste Brasileiro A Respeito Das Mudanças Climáticas: O Caso Do Litoral De Fortaleza CE. p. Disponivel em http:// www.scielo.mec.pt/ scielo.php.

Mello, A.Y.I, D I Giulio, G.M., Ferreira, Lucia, C., Batistella, M., Carmo, R.L. (2012). Abordagem quantitativa em estudos sobre percepção de riscos às mudanças climáticas e ambientais: proposta no litoral norte de São Paulo. VI Annpas. A nais...Belém-PA.

Molua, E., Lambi, C. (2006). Climate Hydrology and Water Resources in Cameroon. CEEPA, Pretoria.
Neuman, W. (2003.) Social Research Methods; Qualitative and Quantitative Approaches. Fifth Edition. Boston.

Neumann, B., Vafeidis, A.T., Zimmermann, J., Nicholls, R.J. (2015). Future Coastal Population Growth and Exposure to Sea-Level Rise and Coastal Flooding - A Global Assessment. - A Global Assessment. PLOS ONE 10(6), e 0131375 . https:// doi.org/10.1371/ journal.pone.0131375.

NOAA, (National Centers for Environmental Information, State of the Climate) (2017). Global Climate Report for March 2017, https:// www.ncdc.noaa.gov/ sotc/ global/ 201703.

Oluseyi, O.F., Oloukoi, J. (2013). Indigenous Knowledge System and Local Adaptation Strategies to Flooding in Coastal Rural Communities of Nigeria. Journal of Indigenous Social D evelopment 2 (1), 1-19.

O nya, C. (2016). Sea level rise and its effects on the West Coast of Mount Cameroon. A Masters thesis defended at the University of Buea Cameroon in partial fulfilment for the award of MSc. in Natural Resource and Environmental Management, 100pp.

O uabo, R.E., Tchoffo, R.S., Ngatcha, B.R. (2018). Utilisation de la géomatique pour l'analyse des risques liés à la dynamique du trait de côte à Kribi. Journal of the Cameroon Academy of Sciences 14 (2), 121-136.

Parlichev, D., Parlichev, G. (2003). Engineeringbiological method for coastal protection. Building the European Capacity in Operational O ceanography, Proceedings of the Third International Conference on EuroGOOS, 574576, doi:10.1016/s0422-9894(03)80093-4. 
Shrestha, B. (2019). Approach for Analysis of Land-Cover Changes and their impact on Flooding Regime. Quaternary 2(3), 27, 10.3390/ quat2030027.

Skaggs, R.W.D., Amatya, M., Chescheir, G. M., Blanton, C. D., Gilliam, J. W. (2006). Effects of drainage and management practices on hydrology of pine plantation. In Proc. Intl. Conf. on Hydrology and Management of Forested Wetlands, 314.

Sun, G., Riedel, M., Jackson, R., Kolka, R., Amatya, D., Shepard, J. (2004). Influences of Management of Southern Forests on Water Quantity and Quality. In: Gen. Tech. Rep. SRS75. A sheville, NC: U.S. D epartment of Agriculture, Forest Service, Southern Research Station. Chapter 19, 195-234.

Tanyui, N.C. (2020). Climate anomalies and its effect on Limbe flood patterns. A thesis submitted to the Faculty of Science, University of Buea, Cameroon in partial fulfilment for the award of a Masters of Science degree in Disaster Risk Management, 99pp.

Teotia, H. S., Ulbricht, K. A., Civco, D. L. (1992). The integration of remote sensing and GIS technologies for land development and irrigation potential in the state of Ceara, Brazil. In: Proceedings of the XVII ISPRS Congress, Washington D.C. Int. Arch. Photogramm. Remote Sensing 29 (B7), 466-472.

Ulbricht, K. A., Teotia, H. S., Civco, D. L., (1992). Supervised Classification to Land Cover Mapping in the Semi-A rid Environment of NE-Brazil using LAND SAT-TM and SPOT D ata. In: Proceedings of the XVII ISPRS Congress, Washington D.C. Int. Arch. Photogramme. Remote Sensing 29 (B7), 821-827.
Viegas, V.A. (2014). Eventos extremos e Saberes Plurais: Percepções e Racionalidades sobre as Alterações Climáticas entre os pescadores da pesca artesanal e costeira de Peniche. UNIVERSIDADE ABERTA, Lisboa.

Vineyard Conservation Society (VCS) (2018). Coastal Erosion Adaptation Strategies. Vineyard Haven, MA 02568.

Vitousek, S., Barnard, P., Fletcher, C. et al. Doubling of coastal flooding frequency within decades due to sea-level rise. Sci Rep 7, 1399. https:/ / doi.org/ 10.1038/ s41598-017-01362-7.

Vousdoukas, M. I., Mentaschi, L., Voukouvalas, E., Verlaan, M., Jevrejeva, S., Jackson, L. P. (2018). Global probabilistic projections of extreme sea levels show intensification of coastal flood hazard. Nature Communications 9, 1-12.

Vousdoukas, M. I., Voukouvalas, E., Mentaschi, L., Dottori, F., Giardino, A., Bouziotas, D. (2016). D evelopments in large-scale coastal flood hazard mapping. Natural Hazards and Earth System Sciences 16, 1841-1853.

Wadey, M.P., Cope, S.N., Nicholls, R.J., McHugh, K., G rewcock, G., Mason, T. (2015). Coastal flood analysis and visualization for a small town. Ocean \& Coastal Management 116, 237247.

Wahl, T., Haigh, I.D., Nicholls, R.J., Arns, A., D angendorf, S., Hinkel, J. (2017). Understanding extreme sea levels for broad-scale coastal impact and adaptation analysis. Nature Communications 8, 16075-1607.

Wong, P. P., Losada, I. J., G attuso, J.P., Hinkel, J., Khattabi, A., McInnes, K.L. (2014). Coastal Systems and Low-Lying A reas. Climate Change2014: Impacts, Adaptation, and 
Vulnerability. Part a: Global and Sectoral Aspects. Contribution of Working Group II to the Fifth Assessment Report of the Intergovernmental Panel on Climate Change. Cambridge: Cambridge University Press.

Woodward, A. (2019). Far more people are threatened by rising seas than scientists realized, a study shows: "The magnitude of the numbers speaks for itself". Business Insider, https:// www.businessinsider.nl/ sea-levl-rise-floodingrisk-higher-estimates-2019-10/.

Zhang, K., D ouglas, B., Leatherman, S. (2000). Twentieth century storm activity along the U.S. East Coast. Journal of Climate, 13, 1748-1761. 